\title{
Toxicokinetics of ergovaline in the horse after an intravenous administration
}

\author{
Sylvie BONY*, Andrée DuRIX ${ }^{\mathrm{a}}$, Agnès LEBLOND ${ }^{\mathrm{b}}$, \\ Philippe JAUSSAUD ${ }^{\mathrm{a}}$
a UMR 188 INRA-ENVL Comparative Metabolism and Toxicology of Xenobiotics, School of Veterinary Medicine of Lyon, 1, avenue Bourgelat, BP 83, 69280 Marcy l'Étoile, France
${ }^{\mathrm{b}}$ Équine Department, School of Veterinary Medicine of Lyon, 1, avenue Bourgelat, \\ BP 83, 69280 Marcy l'Étoile, France
}

(Received 19 February 2001; accepted 3 May 2001)

\begin{abstract}
The toxicokinetics of ergovaline (an ergopeptine mycotoxin present in some grasses infected with endophytic fungus of the genus Neotyphodium) were studied after intravenous administration of a single dose of $15 \mu \mathrm{g} / \mathrm{kg}$ bwt in four gelding horses. Plasma ergovaline concentrations were measured by high performance liquid chromatography, and the kinetic data were described by a three-compartment model. The elimination half-life and the total clearance of ergovaline were found to be $56.83 \pm 13.48 \mathrm{~min}$ and $0.020 \pm 0.004 \mathrm{~L} / \mathrm{min} \cdot \mathrm{kg}$, respectively. According to the toxicological data previously reported in the horse, and in spite of the very low dose administered, clinical signs were observed, including excessive coolness of the ears and the nose, excessive sweating and prostration.
\end{abstract}

ergovaline / mycotoxin / horse / kinetics / Neotyphodium

Résumé - Étude toxicocinétique de l'ergovaline chez le cheval après injection intraveineuse. Les paramètres toxicocinétiques de l'ergovaline (un alcaloïde ergopeptidique présent dans les graminées porteuses d'un champignon endophyte du genre Neotyphodium) ont été déterminés après l'injection intraveineuse d'une dose de $15 \mu \mathrm{g} / \mathrm{kg}$ chez quatre chevaux hongres. Les concentrations plasmatiques d'ergovaline ont été mesurées par chromatographie liquide haute performance et les données cinétiques décrites selon un modèle à trois compartiments. La demi-vie d'élimination et la clairance totale de l'ergovaline ont été respectivement de 56,83 $\pm 13,48 \mathrm{~min}$ et de $0,020 \pm 0,004 \mathrm{~L} / \mathrm{min} \cdot \mathrm{kg}$. Malgré la très faible dose administrée, des signes cliniques compatibles avec les données toxicologiques rapportées dans l'espèce équine ont été observés, à savoir hypothermie des oreilles et du nez, hypersudation et prostration.

ergovaline / mycotoxine / cinétique / cheval / Neotyphodium

* Correspondence and reprints

Tel.: (33)4 788725 29; fax: (33)4 788700 39; e-mail: s.bony@ vet-lyon.fr 


\section{INTRODUCTION}

Ergovaline (Fig. 1) $[3,8,17]$ is the most prevalent (85-97\%) of all ergopeptine alkaloids present in certain grasses, like tall fescue (Festuca arundinacea) or perennial ryegrass (Lolium perenne), infected with an endophyte fungus of the genus Neotyphodium [4, 12, 18, 19]. The presence of the fungus in the plant tissues is beneficial to the host (mutualistic symbiosis), but can be strongly detrimental to herbivorous animals fed an endophyted forage. As in cattle, in horses and particularly in gravid mares, ergovaline is known to be one of the major contributors of "fescue toxicosis". In the equine species, the main symptoms are: excessive sweating, lameness, and many reproductive disorders (prolonged gestation, abortion, dystocia, retained and thickened placenta, abnormal foal maturation, agalactia and foal deaths) $[1,5,6,16]$. Also, reduced serum prolactin and progesterone levels occurred in mares consuming endophyte-infected grasses $[2,15]$. The mechanisms which cause the reproductive problems in the mare have still not been completely clarified. However, it is known that ergovaline acts like dopamine which suppresses the production of the reproductive hormone prolactine, essential to the final stages of pregnancy, birth and lactation. Ergovaline toxic levels in infected plants are around $1 \mathrm{mg} \cdot \mathrm{kg}^{-1}$ (ppm) [18].

The study of the fate of a mycotoxin in the blood provides interesting data (clearance, half-life...) for understanding the potential noxious effect of the compound although it is not sufficient to assess toxicity itself. Recently, plasma kinetics of ergovaline have been studied in sheep [11] and goats [7]. However, to date, it has not been easy to develop toxicokinetic studies based on the dosing of large animals like horses with the pure toxin, because it is in very short supply. Because of this lack of information, the present study was undertaken in order to determine the kinetic parameters

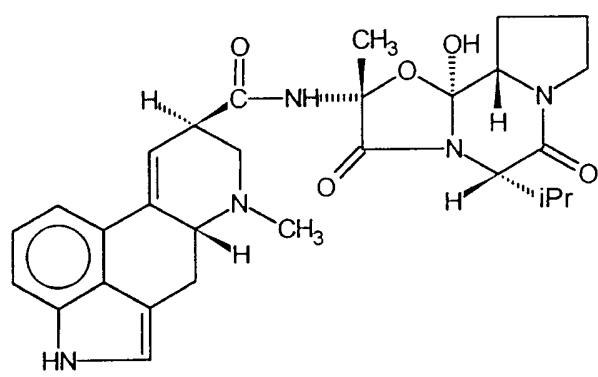

Figure 1. Structure of ergovaline.

of ergovaline, after an intravenous administration in horses.

\section{MATERIALS AND METHODS}

\subsection{Animals and ergovaline administration}

Four gelding horses, aged between 4 and 6 years and weighing about $500 \mathrm{~kg}$ bwt, were kept in individual boxes throughout the experiment. Each animal, which was catheterised (Angiogath, Becton-Dickinson, USA) in the left jugular vein fifteen minutes before the experiment, received a dose of $15 \mu \mathrm{g} / \mathrm{kg}$ bwt ergovaline (provided by Dr. F. Smith., Auburn University, Alabama, USA, $98 \%$ purity) into the right jugular vein. The toxin was administered in the form of tartaric salt, in solution with $2 \mathrm{~mL}$ of a mixture of methanol-sterile physiological serum $(1: 1, \mathrm{v} / \mathrm{v})$.

\subsection{Sample collecting and analysis}

Blood samples were collected from the catheter into heparinised tubes, at $0,1,2,3$, $4,6,8,10,15,30,45,60,90,120$ and $150 \mathrm{~min}$ post dosing. The samples were kept on ice and in the dark, then rapidly centrifuged at $4{ }^{\circ} \mathrm{C}$ for $20 \mathrm{~min}$ at $900 \mathrm{~g}$. Plasma 
was removed and stored at $-20{ }^{\circ} \mathrm{C}$ until analysis. For each sampling time, an aliquot of plasma was analysed according to a previously described high-performance liquid chromatographic method, using ergotamine as internal standard [11]. Briefly, the method consisted in a simple extraction procedure with diethyloxide followed by an HPLC analysis on a Zorbax $\mathrm{C}_{18}$ column, with the excitation and emission wavelength fixed at 250 and $420 \mathrm{~nm}$ respectively on a fluorimetric detector. The method was improved by using $4 \mathrm{~mL}$ of plasma for analysis, instead of $1 \mathrm{~mL}$ as in [11]. After a standard validation procedure, the limit of quantification (LOQ) was lowered from $3.5 \mathrm{ng} / \mathrm{mL}$ to $0.7 \mathrm{ng} / \mathrm{mL}$ of horse plasma.

\subsection{Kinetic data analysis}

A kinetic analysis of the concentration profiles was performed, using a programme for the residuals method. The number of exponents needed for each set of data was determined using the SIPHAR (v. 4. 0) software [10]. The total area under the plasma concentration time curve (AUC), was calculated by linear trapezoidal rule without extrapolation to infinity. The plasma concentration at $t=0\left(C_{0}\right)$ and the volume of the central compartment $\left(V_{\mathrm{C}}\right)$ were calculated with the usual equations [9].

Each individual plasma profile could be fitted to the following tri-exponential function, characterizing a three-compartment model, and a three-phase kinetic process:

$$
C=\mathrm{A}_{1} \mathrm{e}^{-\lambda_{1} t}+\mathrm{A}_{2} \mathrm{e}^{-\lambda_{2} t}+\mathrm{A}_{3} \mathrm{e}^{-\lambda_{3} t}
$$

where $A_{1}, A_{2}$ and $A_{3}$ are ordinar intercepts, and $\lambda_{1}, \lambda_{2}$ and $\lambda_{3}$ are slope values [9]. The tri-exponential function was chosen because it resulted in the best fitting of the experimental data (correlation coefficient of 0.9997 for the terminal phase).

\section{RESULTS}

The logarithmic plot of the mean plasma ergovaline concentration versus time, after intravenous administration, is shown in Figure 2. A very rapid decrease of the mycotoxin plasma levels occurs, the LOQ being reached 150 min post-dosing.

The individual values of different kinetic parameters for each horse are presented in Table I. The plasma clearance and the elimination half-life for terminal phase $\left(\lambda_{3}\right)$ of ergovaline were found to be $0.020 \pm 0.004 \mathrm{~L} / \mathrm{min} \cdot \mathrm{kg}^{-1}$ body weight and $56.83 \pm 13.48 \mathrm{~min}$, respectively.

All animals treated showed the same clinical signs, observed about half an hour after the ergovaline injection: coolness of the ears and the nose, excessive sweating, prostration, and difficulty in urination.

\section{DISCUSSION}

The plasma clearance and the elimination half-life for terminal phase $\left(\lambda_{3}\right)$ of ergovaline obtained in horse are of the same order as those obtained in sheep and goats (0.020 L/min $\cdot \mathrm{kg}^{-1}$ body weight ; $23.6 \mathrm{~min}$, and $0.034 \mathrm{~L} / \mathrm{min} \cdot \mathrm{kg}^{-1} ; 32.4 \mathrm{~min}$, respectively) using a two-compartment model [7, 11].

The clinical signs, similar to those previously observed in goats [7] and in horses [14], are in accordance with the known acute effects of the toxin [13], particularly those linked to the peripheral vasoconstrictive activity of ergot alkaloids.

The rapid decrease of ergovaline in blood, observed after intravenous administration in horses, is of particularly great interest: it indicates that low mycotoxin plasma levels should be expected in animals, after ingestion of grass infected with Neotyphodium. A more complete kinetic study should be undertaken in order to determine the paths (urine or/and bile) which are involved in the elimination of ergovaline in 


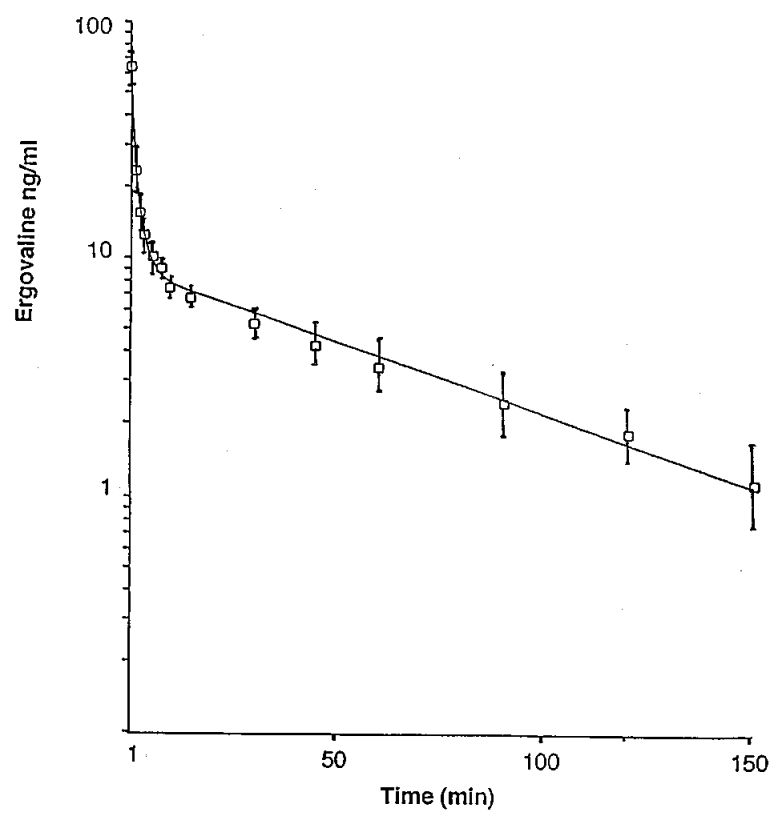

Figure 2. Plasma log.ergovaline concentration versus time profile in horses (mean $\pm \mathrm{sd}, n=4$ ), after an intravenous administration of a single dose of $15 \mu \mathrm{g} / \mathrm{kg} \cdot \mathrm{bwt}$.

Table I. Toxicokinetic parameters describing the disposal kinetics of ergovaline in plasma after an intravenous administration $(15 \mu \mathrm{g} / \mathrm{kg}$.bwt) in four horses.

\begin{tabular}{lcccccc}
\hline $\begin{array}{l}\text { Kinetic parameters } \\
\text { (units) }\end{array}$ & Horse 1 & Horse 2 & Horse 3 & Horse 4 & Mean & SD \\
\hline$\lambda_{1}$ per min) & 1.93 & 2.04 & 1.29 & 1.50 & 1.690 & 0.354 \\
$\lambda_{2}($ per min) & 0.41 & 0.22 & 0.15 & 0.17 & 0.237 & 0.118 \\
$\lambda_{3}$ (per min) & 0.011 & 0.014 & 0.015 & 0.009 & 0.012 & 0.002 \\
$A_{1}(\mathrm{ng} / \mathrm{mL})$ & 278.42 & 389.34 & 160.67 & 179.54 & 251.99 & 105.12 \\
$\mathrm{~A}_{2}(\mathrm{ng} / \mathrm{mL})$ & 22.52 & 19.27 & 9.17 & 6.32 & 14.32 & 7.79 \\
$\mathrm{~A}_{3}(\mathrm{ng} / \mathrm{mL})$ & 8.24 & 7.12 & 7.28 & 7.17 & 7.60 & 0.83 \\
$t_{1 / 2}(\mathrm{~min})$ & 58.89 & 48.91 & 44.58 & 74.94 & 56.83 & 13.48 \\
$\mathrm{Cl}(\mathrm{L} / \mathrm{min} \cdot \mathrm{kg})$ & 0.017 & 0.020 & 0.026 & 0.018 & 0.020 & 0.004 \\
$\mathrm{AUC}(\mathrm{ng} \cdot \mathrm{min} / \mathrm{L})$ & 949.80 & 779.11 & 653.80 & 932.42 & 828.78 & 139.61 \\
$\mathrm{MRT}(\mathrm{min})$ & 67.43 & 46.11 & 46.85 & 90.22 & 62.65 & 20.86 \\
Vc $(\mathrm{L} / \mathrm{kg})$ & 0.048 & 0.036 & 0.085 & 0.078 & 0.062 & 0.024 \\
Co $(\mathrm{ng} / \mathrm{mL})$ & 309.78 & 415.73 & 177.12 & 193.03 & 273.92 & 115.52 \\
& & & & & & \\
\hline
\end{tabular}

$\mathrm{A}_{1}, \mathrm{~A}_{2}, \mathrm{~A}_{3}=$ pre-exponential constants; $\lambda_{1} \lambda_{2} \lambda_{3}$, exponential constants for triexponential equation; $t_{1 / 2} z$ half-life for terminal phase; $\mathrm{Cl}=$ body clearance; $\mathrm{AUC}=$ area under the plasma concentration curve; $\mathrm{MRT}=$ mean residence time calculated until the last sampling time; $\mathrm{Vc}=$ volume of the central compartment $(\mathrm{Vc}=\mathrm{Xo} / \mathrm{Co}$ where $\mathrm{Xo}$ is the administred dose); $\mathrm{Co}=\mathrm{A}_{1}+\mathrm{A}_{2}+\mathrm{A}_{3}$. 
the equine species. Moreover, the dose of $15 \mu \mathrm{g} / \mathrm{kg}$ could be used as a toxicity threshold, in the absence of quantitative toxicological data (NOAEL: no observed adverse effect level, LOEL: lowest observed effect level) concerning ergovaline.

\section{ACKNOWLEDGEMENTS}

The authors gratefully acknowledge the skilled technical assistance of Monique Carcelen, Colette Huc and Christian Paquet. They also wish to thank Alain Vigié who performed the kinetic analysis, Dr. Stephane Martinot who gave his help for the jugular catheterisation and Mrs Maureen Bocquet (BSc honor.) for her reading of the English manuscript.

\section{REFERENCES}

[1] Bacon, C.W., Lyons P.C., Porter J.K., Robbins J.D., Ergot toxicity from endophyte-infected grasses: A review, Agron. J. 78 (1986) 158-163.

[2] Brendemuehl J.P., Carson R.L., Wenzel J.G.W., Boosinger T.R, Shelby R.A., Effects of grazing endophyte-infected tall fescue on ECG and progestogen concentrations from gestation day 21 to 300 in the mare, Theriogenology 46 (1996) 85-96.

[3] Brunner R., Stütz P.L., Tscherter H., Stadler P.A., Isolation of ergovaline, ergoptine and ergonine, new alkaloids of the peptide type, from ergot sclerotia, Can. J. Chem. 57 (1979) 1638-1641.

[4] Craig A.M., Bilich D., Hovermale J.T., Welty R.E., Improved extraction and HPLC methods for ergovaline from plant material and rumen fluid, J. Vet. Diagn. Invest. 6 (1994) 348-352.

[5] Cross D.L., Fescue toxicosis in horses, in: Bacon C.W., Hills N.S. (Ed.), Neotyphodium / Grass Interactions. Plenum Press, New-York, 1997, pp. 289-309.

[6] Cross D.L., Redmond L.M., Strickland J.R., Equine fescue toxicosis: signs and solutions, J. Anim. Sci. 73 (1995) 899-908.

[7] Durix A., Jaussaud P., Garcia P., Bonnaire Y., Bony S., Analysis of ergovaline in milk using high-performance liquid chromatography with fluorimetric detection, J. Chromatogr. B 729 (1999) 255-263.
[8] Garner G.B., Rottinghaus G.E., Cornell C.N., Testereci H., Chemistry of compounds associated with endophyte/grass interaction: ergovaline - and ergopeptine - related alkaloids, Agric. Ecosyst. Environ. 44 (1993) 65-80.

[9] Gibaldi M., Perrier P., Pharmacokinetics, Dekker Inc., New York and Basel, 1975, pp. 89-95.

[10] Gomeni C., Gomeni R., SIPHAR: an integrated computer system for statistical and pharmacokinetic data analysis In: Proceedings of the Seventh International Congress of Medical Informatics, Serio A., O'Moore R., Tardini A., Roger F.H. (Eds.), European Federation for Medical Informatics, Roma, 1987, pp. 507-516.

[11] Jaussaud P., Durix A., Videmann B., Vigié A., Bony S., Rapid analysis of ergovaline in ovine plasma using high-performance liquid chromatography with fluorimetric detection, J. Chromatogr. A 815 (1998) 147-153.

[12] Lyons P.C., Plattner R.D., Bacon C.W., Occurrence of peptide and clavine ergot alkaloids in tall fescue grass, Science 232 (1986) 487-489.

[13] Oliver J.W., Physiological manifestation of endophyte toxicosis in ruminant and laboratory species, in: Bacon C.W., Hills N.S. (Ed.), Neotyphodium/Grass Interactions, Plenum Press, NewYork, 1997, pp. 311-346.

[14] Putnam M.R., Bransby D.I., Schumacher J., Boosinger T.R., Bush L., Shelby R.A., Vaughan J.T., Ball D., Brendemuehl J.P., Effects of the fungal endophyte Acremonium coenophialum in fescue on pregnant mares and foal viability, Am. J. Vet. Res. 52 (1991) 2071-2074.

[15] Redmond L.M., Cross D.L., Strickland J.R., Kennedy S.W., Efficacy of domperidone and sulpiride for fescue toxicosis in horses, Am. J. Vet. Res. 55 (1994) 722-729.

[16] Rohrbach B.W., Green E.M., Oliver J.W., Schneider J.F., Aggregate risk study of exposure to endophyte-infected (Acremonium coenophialum) tall fescue as a risk factor for laminitis in horses, Am. J. Vet. Res. 56 (1995) 22-26.

[17] Stadler P.A., Frey A.J., Ott H., Hofmann A., Die Synthese des Ergosins und des Valin-Analogen der Ergotamin-Gruppe, Helv. Chim. Acta 46 (1964) 1911-1921.

[18] Thompson F.N., Stuedemann J.A., Pathophysiology of fescue toxicosis, Agric. Ecosyst. Environ. 44 (1993) 263-281.

[19] Yates S.G., Plattner R.D., Garner G.B., Detection of ergopeptine alkaloids in endophyteinfected, toxic KY-31 tall fescue by mass spectrometry/mass spectrometry, J. Agric. Food. Chem. 33 (1985) 719-722. 